\title{
The Impact of Activity-Based Oral Expression Course on Speech Self-Efficacy of Students
}

\author{
Hatice Altunkaya \\ Correspondence: Hatice Altunkaya, Adnan Menderes University, Turkey. \\ Received: December 2, 2017 \\ Accepted: December 24, 2017 Online Published: December 28, 2017 \\ doi:10.11114/jets.v6i1.2832 \\ URL: https://doi.org/10.11114/jets.v6i1.2832
}

\begin{abstract}
The objective of the present study was to examine the effect of the activity-based oral expression course on the speech self-efficacy of psychological counseling and guidance students. The study group included 80 freshmen students in the Psychological Counseling and Guidance Department in the Faculty of Education of a university located in western Turkey. Quantitative data were collected with the "Speech Self-Efficacy Scale" developed by Katranci and Melanlioglu (2013). Qualitative data were obtained with the descriptive and content analysis of student views. It was found that the difference between the group averages obtained with the paired group t-test that was conducted on the measurement variable of the mean student speech self-efficacy scores was statistically significant $(\mathrm{t}(158)=-3.335 ; \mathrm{p}=0.001<0.05)$. The posttest speech self-efficacy scores $(\overline{\mathrm{x}}=96.025)$ were higher than the pretest speech self-efficacy scores $(\overline{\mathrm{x}}=$ 89.213). Based on the qualitative research the results of the present research demonstrated that students considered the activity-based oral expression course beneficial for all sources of self-efficacy beliefs, including direct experiences, indirect experiences, verbal persuasion and emotional state.
\end{abstract}

Keywords: oral expression, self-efficacy, speech self-efficacy perception

\section{Introduction}

\subsection{Speech Self-Efficacy Perception}

Speech training involves a process that requires the co-operation of complex mental, cognitive and affective skills. In this process, learners' willingness to speak, their judgments about their own speech, their concerns before and during the conversation are among the factors that affect the verbal skills of students in the affective dimension of speech. The development of verbal skills is directly associated with sciences such as psychology, social psychology, behavioral and communication sciences (Unalan, 2007: 2-3). Verbal skill, which is a social skill, can be affected positively or negatively based on the anxiety and self-efficacy perception levels of the students.

The concept of self-efficacy that was introduced by Bandura, who developed the social learning theory, can be described as a set of beliefs and judgments that an individual has on whether she or he can succeed in a given task. Self-efficacy is preliminary views of individuals on their own capacity to organize and implement activities necessary to perform certain tasks (Bandura, 1986). The self-efficacy perception of an individual can be developed based on self-experiences or on the role models in the social environment or by comparing the results of her or his own attitudes and behavior with others (Bandura, 1997). Bandura (1986) suggests that there are four sources of self-efficacy beliefs; namely performance achievements based on individuals' own experiences, indirect experiences, verbal persuasion and emotional state. Successful experiences of the student during the learning process can lead to the development of positive self-efficacy beliefs, while unsuccessful experiences may lead to negative self-efficacy beliefs. Individuals who organize the conditions, observe, reevaluate, and deduce results could construct their self-efficacy based on their achievements in the task at hand. The positive achievements of the individual increase self-efficacy perception, while the negative outcomes lead to a decrease in self-efficacy (Schunk, 2003: 160).

The beliefs that the students acquire by comparing their own achievements or failures with their peers' in the learning process are indirect experiences. Verbal persuasion is based on the conviction of the student by the family, peers, and teachers that the student can successfully perform the task at hand. Several studies identified that verbal persuasion has an impact on self-efficacy belief (Lopez, Lent, Brown and Gore, 1997; Pajares, Johnson and Usher, 2007: White, 2009). The emotional state is related to the belief of the student that learning is associated with her or his emotional state based on the fact that learning has both cognitive and affective aspects. 
According to Schunk (2008), the self-efficacy perception plays an important role in the learning process, and in this process, self-efficacy perception is a balancing factor and those with low self-efficacy beliefs tend to consider the tasks and situations harder than they really are, leading to increased levels of stress and subjective beliefs. Based on the aforementioned information, speech self-efficacy of the students can be defined as judgments about self-efficacy beliefs in speech, whether the student is competent in his / her speech, and whether the student can perform the speech tasks adequately. Bircan (2013: 109) stated that a large proportion of university students do not have sufficient self-confidence in verbal skills and individuals with self-confidence problems experience problems in expressing themselves, and even can fail in speech in fear of making mistakes. Students' speech self-efficacy perceptions may differ depending on previous verbal performances, their self-assessment in comparison with their peers in the classroom or environment, or verbal persuasion of their teachers, friends, and teachers, or their emotional state. Verbal skill is a social skill since it is a skill that can be performed with multiple individuals due to the requirement of the receptive element that is the basis of communication when compared to other language skills. Ayan, Katranci and Melanlioglu (2014) stated that the language skill that most pre-service teachers experience problems with is verbal skills. In verbal skills, the cognitive aspect as well as the affective aspect of the learner are both engaged. Arslan (2012: 229) investigated the views of university students about speaking before an audience and concluded that a great majority of students wanted to speak before an audience but refrained from doing so even when they have a chance or abstain from the tasks related to speaking before an audience due to factors such as inability to articulate in Turkish, learning Turkish as a second language, the fear of providing incorrect or incomplete information, cynical behavior of the audience, lack of self-confidence, shyness, elocution problems, and anxiety about misunderstanding. When these findings are associated with self-efficacy beliefs, it can be observed that lack of self-confidence is related to beliefs on the performance based on the self-efficacy belief sources, and shy temperament is associated with the emotional state, one of the self-efficacy belief sources. The cynical behavior of the audience can be attributed to the indirect experiences source of the students' speech self-efficacy perceptions and the anxiety of misunderstanding can be related to the lack of verbal persuasion. Speech self-efficacy perceptions are the judgments of the individuals about their competency in speech. If the speech self-efficacy of a student, who is assigned to give a prepared speech, is low, the student can face problems such as inability to fulfill the task and avoid to speak (Katranci, 2014: 177). Students, especially pre-service teachers, who would rely on speech to perform their profession in the future, need to be successful in verbal skills. Improvement of speech self-efficacy, which is the judgment of individuals about their own speech, could lead to the success of individuals. Research on the correlation between self-efficacy and academic achievement (Erdem, Altunkaya and Ates, 2017; Ulper ve Bagci, 2012; Schunk and Zimmerman, 2007; Bandura and Locke, 2003) revealed that self-efficacy has an impact on academic achievement. Education is a process that requires the supportive role of cognitive, affective and psychomotor skills. Although the self-efficacy perception, which is in the affective dimension of the process, is not the sole determinant of achievement, it is a significant factor, the contribution of which in success was revealed in several studies.

\subsection{Activity-Based Instruction}

Activity based instruction is one of the constructivist teaching strategies. The activity-based instruction approach includes a variety of activities for the students. The activity-based learning approach, where learners learn by experiencing and doing, encourages the students to associate concepts, develop their own learning strategy, and ensures permanency of learning (Mert Cuce, 2012: 14). This approach is one of the approaches that are effective in the development of language skills. The most effective method to develop students' comprehension and verbal skills is to develop educational measures that will make the student active and guide the student towards practice (Sever, 2001). Aktas and Gunduz (2009) stated that speech education can be conducted by practice similar to writing education rather than memorizing certain formulas. Improvement of the verbal skills of students cannot be achieved by memorizing basic information about speech. For this purpose, students should be included in the education process and should be able to learn permanently by experiencing and doing through various activities. The condition that students are more active than teachers in the classroom environment is an emphasized characteristic in obtaining the desired productivity in education and instruction activities. Teachers should create a classroom environment where the students can express themselves easily. Thus, every opportunity that would enable the students to speak should be utilized (Dogan, 2009: 194).

Basaran and Erdem (2009: 753) reported that the pre-service teachers stated that college education had a positive effect on their eloquent speaking skills, however the oral expression course was insufficient for the development of this skill. Thus, it is considered that there is a need to conduct further research on the oral expression courses and to reorganize the educational environment based on the results of such research. Based on this information, the effect of activity-based oral expression course on the self-efficacy levels of the students, which has an impact on student achievements, is considered as the basis of the present study.

Students with high self-efficacy perceptions are less concerned about the responsibilities brought by the tasks they face. 
As the belief that they could succeed at the task increases, the pressure they experience decreases (Wood and Bandura, 1989). There are several studies on the self-efficacy perception of pre-service teachers in the literature (Gunay, 2003; Oguz, 2009; Ciftci and Taskaya, 2010; Katranci, 2014). These studies investigated the self-efficacy perceptions of pre-service teachers based on various variables, however no applied study was conducted to improve the speech self-efficacy perception positively. To improve the speech self-efficacy perception that has an impact on the acquisition of verbal skills, it is of great importance to research whether activity-based instruction in oral expression course could contribute to this end since it could provide a roadmap for oral expression course instructors and students. Previous studies reported that there was no significant difference between the speech self-efficacy perceptions of pre-service teachers based on the gender variable (Akin, 2016; Ciftci and Taskaya, 2010; Yilmaz and Cimen, 2008; Gunay, 2003). Certain studies in the literature reported that speech self-efficacy perception levels of female pre-service teachers were higher than that of male pre-service teachers (Katranci, 2014; Kilcigil, Bilir, Özdinç, Eroglu and Eroglu, 2009; Ozerbas, Bulut and Usta, 2007). It was observed in previous studies that the self-efficacy perceptions of students differed based on gender. It was considered that it would be beneficial to investigate the self-efficacy perceptions of the students based on the gender variable in activity-based oral expression course and to make recommendations for the oral expression course based on the said research. Verbal skills that include speech, listening, reading and writing skills support each other. The learning in one domain, supports learning in the other. Utilization of reading performance could be considered a requirement to determine the effect of the reading performance on the speech skills and to succeed in oral expression courses. The idea that storybook reading promotes language development was supported by correlational, experimental, and intervention studies (Scarborough \& Dobrich, 1994; Bus, van IJzendoorn, \& Pellegrini, 1995).

The objective of the study was to determine the effect of the activity-based oral expression course on speech self-efficacy perceptions of Psychological Counseling and Guidance Department students. Within the scope of this objective, the following sub-problems were established:

1. What are the self-efficacy perception levels of students before and after the activity-based oral expression course? Is there a significant difference between the pre-test and post-test scores of the students on the speech self-efficacy perception scale?

2. Is there a difference between the pretest speech self-efficacy perception levels of the students based on gender?

3. Is there a difference between the pretest speech self-efficacy perception levels of the students based on the number of books they read during the previous year?

4. Is there a difference between the posttest speech self-efficacy perception levels of the students based on gender?

5. Is there a difference between the posttest speech self-efficacy perception levels of the students based on the number of books they read during the previous year?

6. What are the views of the students on the activity-based instruction of the oral expression course?

\section{Methodology}

\subsection{Participants}

The study was conducted as an embedded mixed design research using both quantitative and qualitative data. In this design, one of the qualitative and quantitative methods is more prominent than the other. In other words, research is predominantly a qualitative or a quantitative study, but there is also a need for the data obtained with an alternative method to support, generalize, or explain the acquired data (Cresswell and Plano Clark, 2007). Thus, the research questions were mostly associated with the quantitative method and the qualitative data obtained with document analysis were utilized to explain the quantitative data. Quantitative data were obtained with a single group pretest-posttest model and qualitative data were obtained with descriptive and content analysis conducted on the notes written by the students before the activities, during the activities, and after the activities on the activities they conducted in the classroom. In the single group pretest-posttest design used to obtain the quantitative study data, the pretest was applied to a group, then the experimental process is conducted and finally a posttest was applied (Creswell, 2003). In this context, the pre-test was applied at the beginning of 2016/2017 academic year spring semester and posttest was applied at the end of the same semester. Following the pre-test, activity-based oral expression classes were instructed throughout the semester. Quantitative study data were analyzed with SPSS 22 software and qualitative data were analyzed by descriptive and document analysis. In the evaluation of the data, counts, percentages, mean and standard deviation values were used as descriptive statistical methods. The paired group t-test was used to determine the difference between the measurements. One-way ANOVA test was utilized to compare the quantitative continuous data between more than two independent groups and the comparison of quantitative continuous data between two independent groups was conducted with t-test. The Scheffe test was used as a complementary post-hoc analysis to determine the differences after the ANOVA test. Findings were evaluated in 95\% confidence interval and 5\% significance level. 
The study group included 80 freshmen students in Faculty of Education, Psychological Counseling and Guidance Department in a university in western Turkey.

Table 1. Participant demographics

\begin{tabular}{llll}
\hline Tables & Groups & Frequency(n) & Percentage (\%) \\
\hline Gender & Female & 55 & 68.8 \\
& Male & 25 & 31.2 \\
& Total & 80 & 100,0 \\
Number of books read during the last year & $1-5$ & 33 & 41.2 \\
& $6-11$ & 30 & 37.5 \\
& $12-24$ & 17 & 21.2 \\
& Total & 80 & 100.0 \\
\hline
\end{tabular}

Based on the gender variable, 55 (68.8\%) students were female and $25(31.2 \%)$ were male. Based on the number of books read during the previous year, $33(41.2 \%)$ students read between 1 and 5 books, $30(37.5 \%)$ read between 6 and 11books and $17(21.2 \%)$ read between 12 and 24 books.

\subsection{Data Collection Instruments}

Quantitative and qualitative data collection instruments were used in the research. Speech Self-Efficacy Scale was used as the quantitative data collection instrument. "Speech Self-Efficacy Scale for Pre-Service Teachers," developed by Katranci and Melanlioglu (2014), is a scale that includes 25 items with a five-factor structure and a Cronbach Alpha internal consistency coefficient of .92. The items in the first factor are related to the speaking of the pre-service teacher before an audience and represent the dimension of "speaking before an audience". The items under the second factor represent the effectiveness of speech. This factor is called "effective speech". The third factor establishes the elements that need to be considered before, during and after the speech. Thus, the factor reflects the "application of speech rules" dimension of the scale. The fourth factor is called "organizing the speech content," since it is related to the content of the speech. The fifth factor includes the items related to assessment, hence it is the "assessment of the speech" dimension of the scale (Katranci and Melanlioglu, 2013: 662). In the present study, the reliability of the "Speech Self-Efficacy Scale" was high (Cronbach's Alpha $=0.931)$.

\subsection{Qualitative Data Collection Instrument}

In the study, the data obtained with descriptive and content analyses conducted on the notes written by the students about the activities they performed before, during and after the activities were used as the qualitative data.

\subsection{Implementation Process}

The application phase of the study was conducted in the Faculty of Education in a university located in western Turkey during the 2016-2017 academic year spring semester. In the Psychological Counseling and Guidance Department, a 12 weeks long activity-based oral expression course was instructed. The course was instructed in two class hours per week and in the first hour, the author instructed the class utilizing the constructivist approach. In the second class, the activities that were previously explained by the author were conducted by the students. The book titled "Verbal Education Oral Expression" by Temizyurek, Erdem and Temizkan (2011) was used as the course textbook. The first class was utilized to get to know the students and information was provided for the students on the subject matter and the instruction methodology of the course. Speech Self-Efficacy Scale for Pre-Service Teachers, developed by Katranci and Melanlioglu (2014) was applied in this class. On the final class of the semester, all subjects instructed during the semester were reviewed briefly and the same scale was applied to finalize the collection of the quantitative study data. Based on the selected textbook and activities, the instruction of the course included the following stages:

$1^{\text {st }}$ Week: The topics of communication, communication process, verbal communication, written communication and non-verbal communication were instructed and students' views on these subjects were obtained with question and answer method. The importance of communication for social life, individuals and psychological counseling and guidance students was discussed with the students. The students were divided into groups of 5, 6 or 7 individuals based on their own decision. Activity guidelines for each group were distributed to the students in writing. The date when each student group will present the activity was determined. The activity sequence was organized so that each week an activity related to the topic that was instructed the previous week could take place.

$2^{\text {nd }}$ Week: The content of the non-verbal communication and body language unit were instructed during the first class with the constructivist teaching approach. During the second class, the students conducted an impromptu talking activity. All students in the group briefly presented information about impromptu conversation to the class, then portrayed impromptu speech examples from real life in the class. Impromptu conversation examples that included a job 
application at a hair dresser's, grocery shopping, an address inquiry, etc. were observed with interest by the students in the class and the students exchanged views after the presentation.

$3^{\text {rd }}$ Week: The Physical Elements section of the Speech and Elements of Speech unit was instructed. Information was provided on sound, breathing, inhaling, exhaling, training the physical organs and various sound exercises were conducted with the students in the class. During the second week, the students performed a rhyming activity. The students' creativity emerged in the activities, various costumes they used, and the rhyming activity they conducted as a show, created an environment that allowed the students to learn by having fun.

$4^{\text {th }}$ Week: The Cognitive Elements of Speech were instructed. The relationship between speech and the brain, memory and memory training were emphasized. In that week, students performed the story telling activity and enacted the Deli Dumrul story from the Dede Korkut stories using several costumes and portraying the characters in the story and received great praise from classmates.

$5^{\text {th }}$ Week: The topic of elocution was instructed, and information was provided on the topics of articulation, intonation, pause, connection, melody and poetry reading. The fifth week's activity was the grocery activity. In this activity, the first student says that he bought fruits from the grocery store. The second student adds another fruit to the fruit that the first student purchased, and another student tells the names of the fruits that the first two students said and the fruit that she or he purchased. The activity goes on by increasing the number of fruits. This activity was observed with interest by students since it was an activity that contributed to the mental development of students as a memory-enhancing activity, which is one of the mental aspects of speech.

$6^{\text {th }}$ Week: The instruction continued on the topic of elocution and various exercises were conducted by emphasizing the distinctive features of emphasis and intonation in reading poetry and speech. The conference activity, where important elements of elocution such as emphasis, intonation, and articulation can be exhibited, was conducted.

$7^{\text {th }}$ Week: The Verbal Language Properties of Turkish Unit was instructed. The activity of the seventh week was the guide activity. The students who formed the group described the place of their choice using a visual presentation. The activity, which contributed to the students' verbal skills as well as their general culture, was a class that students followed with interest.

$8^{\text {th }}$ Week: The prepared speech topic in the Types of Speech unit was instructed. Information was provided about the topics of conference, debate, symposium, panel, forum, panel discussion, discourse and interview. In the second class, a debate activity was conducted, and students were asked to emphasize sound properties such as intonation, emphasis etc. during the activity.

$9^{\text {th }}$ Week: Impromptu daily conversations topic was instructed, and communication flaws that could be encountered in the social setting were discussed. The class was organized as a panel discussion. The panel discussion activity was on the current problems of the Turkish language and the students expressed their thoughts in the class environment using the prepared speech type and the students in the audience were informed about the current problems of Turkish language (The resources that the activity group could use were provided to the students by the course instructor a few weeks before the activity).

$10^{\text {th }}$ Week: The Speech Disorders and Their Treatment unit was instructed. The course activity was the "I am cooking" activity where the students discussed cooking. The students who formed the group explained all the steps of cooking a meal of their own region using visual presentations.

$11^{\text {th }}$ Week: The significance of verbal skills for Psychological Counseling and Guidance students and the relationship between speech and other language skills were addressed. The activity of the week was "I'm claiming my rights." The students enacted a court, performed the speeches that were adequate for their roles, utilizing all elements of speech.

$12^{\text {th }}$ Week: Assessment and Evaluation in Verbal Skills unit was instructed. Several example speeches related to the speech types mentioned in previous weeks were watched, emphasizing the relationships between body language, the tone of the voice and speech rules. During the last class, the cross-examination activity was conducted by students. Students determined a topic and performed the activity using both physical and mental elements of speech by asking questions to each other.

\section{Results}

\subsection{Quantitative Findings}

Findings obtained to determine the effect of the activity-based oral expression course on the speech self-efficacy perceptions of the Psychological Counseling and Guidance department students are presented below based on the sub-problems of the research:

Findings on the sub-problems of "What are the self-efficacy perception levels of students before and after the 
activity-based oral expression course? Is there a significant difference between the pre-test and post-test scores of the students on the speech self-efficacy perception scale?" are presented in Table 2.

Table 2. Students' mean speech self-efficacy scores

\begin{tabular}{|c|c|c|c|c|c|c|}
\hline \multirow[t]{2}{*}{ Groups } & \multicolumn{2}{|c|}{ Pretest $(n=80)$} & \multicolumn{2}{|c|}{ Posttest $(n=80)$} & \multirow[t]{2}{*}{$\mathrm{t}$} & \multirow[t]{2}{*}{$\mathrm{p}$} \\
\hline & Mean & Sd & Mean & Sd & & \\
\hline Speaking before an audience & 21.850 & 5.077 & 24.913 & 4.976 & -3.853 & 0.000 \\
\hline Effective speech & 22.013 & 3.720 & 23.600 & 3.332 & -2.843 & 0.005 \\
\hline Application of speech rules & 19.238 & 2.978 & 20.088 & 2.649 & -1.908 & 0.058 \\
\hline Organization of speech content & 14.288 & 2.706 & 15.213 & 2.438 & -2.272 & 0.024 \\
\hline Speech assessment & 11.825 & 1.895 & 12.213 & 1.666 & -1.374 & 0.171 \\
\hline Speech Self-Efficacy & 89.213 & 12.945 & 96.025 & 12.896 & -3.335 & 0.001 \\
\hline
\end{tabular}

It was found that the difference between group averages was statistically significant $(t(158)=-3.853, p=0.000<0.05)$ as a result of the paired group t-test conducted to determine whether there was a statistically significant difference between the mean speaking before an audience scores of the students based on the measurement variable. The posttest speaking before an audience scores $(\overline{\mathrm{x}}=24.913)$ were higher when compared to the pretest speaking before an audience scores $(\overline{\mathrm{x}}=$ 21.850).

It was found that the difference between group averages was statistically significant $(\mathrm{t}(158)=-2.843 ; \mathrm{p}=0.005<0.05)$ as a result of the paired group t-test conducted to determine whether there was a statistically significant difference between the mean effective speech scores of the students based on the measurement variable. The posttest effective speech scores $(\overline{\mathrm{x}}=23.600)$ were higher when compared to the pretest effective speech scores $(\overline{\mathrm{x}}=22.013)$.

It was found that the difference between group averages was statistically significant $(t(158)=-2.272 ; \mathrm{p}=0.024<0.05)$ as a result of the paired group t-test conducted to determine whether there was a statistically significant difference between the mean organizing the speech content scores of the students based on the measurement variable. The posttest organizing the speech content scores $(\overline{\mathrm{x}}=15.213)$ were higher when compared to the pretest organizing the speech content scores $(\overline{\mathrm{x}}=14.288)$.

It was found that the difference between group averages was statistically significant $(\mathrm{t}(158)=-3.335 ; \mathrm{p}=0.001<0.05)$ as a result of the paired group t-test conducted to determine whether there was a statistically significant difference between the mean speech self-efficacy scores of the students based on the measurement variable. The posttest speech self-efficacy scores $(\bar{x}=96.025)$ were higher when compared to the pretest speech self-efficacy scores $(\bar{x}=89.213)$.

It was found that the difference between group averages was not statistically significant as a result of the $t$-test conducted to determine whether there was a statistically significant difference between the mean application of speech rules and speech assessment scores of the students based on the measurement variable ( $p>0.05)$.

Findings on the sub-problem of "Is there a difference between the pretest speech self-efficacy perception levels of the students?" are presented in Table 3.

Table 3. Mean pretest speech self-efficacy scores of the students based on gender

\begin{tabular}{lllllll} 
& Group & $\mathrm{N}$ & Mean & $\mathrm{Sd}$ & $\mathrm{t}$ & $\mathrm{p}$ \\
\hline Speaking before an audience Pretest & Female & 55 & 21.873 & 4.911 & 0.059 & 0.953 \\
& Male & 25 & 21.800 & 5.530 & & \\
Effective Speech Pretest & Female & 55 & 22.164 & 3.452 & 0.537 & 0.593 \\
& Male & 25 & 21.680 & 4.308 & & \\
Application of Speech Rules Pretest & Female & 55 & 19.073 & 2.734 & -0.732 & 0.466 \\
& Male & 25 & 19.600 & 3.488 & & \\
Organization of Speech Content Pretest & Female & 55 & 14.073 & 2.686 & -1.054 & 0.295 \\
& Male & 25 & 14.760 & 2.743 & & \\
Speech Assessment Pretest & Female & 55 & 11.982 & 1.758 & 1.100 & 0.275 \\
& Male & 25 & 11.480 & 2.163 & & \\
Speech Self-Efficacy Pretest & Female & 55 & 89.164 & 12.054 & -0.050 & 0.960 \\
& Male & 25 & 89.320 & 14.988 & & \\
\hline
\end{tabular}

It was found that the difference between group averages was not statistically significant as a result of the t-test conducted to determine whether there was a statistically significant difference between the mean pretest speaking before an audience, effective speech, application of speech rules, organization of speech content, speech assessment and speech self-efficacy scores based on gender variable ( $\mathrm{p}>0.05)$.

Findings on whether the speech self-efficacy perception levels of the students varied based on the number of books read within a year are presented in Table 4 . 
Table 4. Mean pretest speech self-efficacy scores of the students based on the number of books read within a year

\begin{tabular}{|c|c|c|c|c|c|c|c|}
\hline & Group & $\mathrm{N}$ & Mean & $\mathrm{Sd}$ & $\mathrm{F}$ & $\mathrm{p}$ & Diff. \\
\hline \multirow{3}{*}{$\begin{array}{l}\text { Speaking before an audience } \\
\text { Pretest }\end{array}$} & 1-5 Books & 33 & 20.636 & 5.165 & \multirow[t]{3}{*}{4.744} & \multirow[t]{3}{*}{0.011} & \multirow{6}{*}{$\begin{array}{l}3>1 \\
3>2\end{array}$} \\
\hline & 6-11 Books & 30 & 21.400 & 4.223 & & & \\
\hline & 12-24 Books & 17 & 25.000 & 5.256 & & & \\
\hline \multirow[t]{3}{*}{ Effective Speech Pretest } & 1-5 Books & 33 & 21.455 & 3.825 & \multirow[t]{3}{*}{3.057} & \multirow[t]{3}{*}{0.053} & \\
\hline & 6-11 Books & 30 & 21.533 & 3.471 & & & \\
\hline & 12-24 Books & 17 & 23.941 & 3.491 & & & \\
\hline \multirow{3}{*}{$\begin{array}{l}\text { Application of Speech Rules } \\
\text { Pretest }\end{array}$} & 1-5 Books & 33 & 19.030 & 2.778 & \multirow[t]{3}{*}{3.757} & \multirow[t]{3}{*}{0.028} & $3>1$ \\
\hline & 6-11 Books & 30 & 18.533 & 3.037 & & & $3>2$ \\
\hline & 12-24 Books & 17 & 20.882 & 2.781 & & & \\
\hline \multirow{3}{*}{$\begin{array}{l}\text { Organization of Speech Content } \\
\text { Pretest }\end{array}$} & 1-5 Books & 33 & 14.303 & 2.733 & \multirow[t]{3}{*}{1.702} & \multirow[t]{3}{*}{0.189} & \\
\hline & 6-11 Books & 30 & 13.733 & 2.434 & & & \\
\hline & 12-24 Books & 17 & 15.235 & 2.990 & & & \\
\hline \multirow[t]{3}{*}{ Speech Assessment Pretest } & 1-5 Books & 33 & 11.424 & 1.888 & \multirow[t]{3}{*}{5.102} & \multirow[t]{3}{*}{0.008} & $3>1$ \\
\hline & 6-11 Books & 30 & 11.567 & 1.794 & & & $3>2$ \\
\hline & 12-24 Books & 17 & 13.059 & 1.638 & & & \\
\hline \multirow[t]{3}{*}{ Speech Self-Efficacy Pretest } & 1-5 Books & 33 & 86.849 & 12.831 & \multirow[t]{3}{*}{5.719} & \multirow[t]{3}{*}{0.005} & $3>1$ \\
\hline & 6-11 Books & 30 & 86.767 & 10.773 & & & $3>2$ \\
\hline & 12-24 Books & 17 & 98.118 & 13.444 & & & \\
\hline
\end{tabular}

It was found that the difference between group averages was statistically significant $(\mathrm{F}=4.744 ; \mathrm{p}=0.011<0.05)$ as a result of one-way analysis of variance (ANOVA) conducted to determine whether there was a difference between the mean pretest speaking before an audience scores of the students who participated in the study based on the number of books read within the year variable. A supplementary post-hoc analysis was conducted to determine the sources of the differences. Speaking before an audience scores of those who read 12-24 books in a year $(25.000 \pm 5.256)$ were higher when compared to those who read $1-5$ books per year $(20.636 \pm 5.165)$. Speaking before an audience scores of those who read 12-24 books in a year $(25.000 \pm 5.256)$ were higher when compared to those who read 6-11 books per year $(21.400 \pm 4.223)$.

It was found that the difference between group averages was statistically significant $(F=3.757 ; p=0.028<0.05)$ as a result of one-way analysis of variance (ANOVA) conducted to determine whether there was a difference between the mean pretest application of speech rules scores of the students who participated in the study based on the number of books read within the year variable. A supplementary post-hoc analysis was conducted to determine the sources of the differences. Application of speech rules scores of the students who read 12-24 books in a year $(20.882 \pm 2.781)$ were higher when compared to those who read 1-5 books per year $(19.030 \pm 2.778)$. Application of speech rules scores of the students who read 12-24 books in a year $(20.882 \pm 2.781)$ were higher when compared to those who read 6-11 books per year $(18.533 \pm 3.037)$.

It was found that the difference between group averages was statistically significant $(\mathrm{F}=5.102 ; \mathrm{p}=0.008<0.05)$ as a result of one-way analysis of variance (ANOVA) conducted to determine whether there was a difference between the mean pretest speech assessment scores of the students who participated in the study based on the number of books read within the year variable. A supplementary post-hoc analysis was conducted to determine the sources of the differences. Speech assessment scores of the students who read 12-24 books in a year (13.059 \pm 1.638$)$ were higher when compared to those who read 1-5 books per year (11.424 \pm 1.888$)$. Speech assessment scores of the students who read 12-24 books in a year $(13.059 \pm 1.638)$ were higher when compared to those who read 6-11 books per year (11.567 \pm 1.794$)$.

It was found that the difference between group averages was statistically significant $(F=5.719 ; \mathrm{p}=0.005<0.05)$ as a result of one-way analysis of variance (ANOVA) conducted to determine whether there was a difference between the mean pretest speech self-efficacy scores of the students who participated in the study based on the number of books read within the year variable. A supplementary post-hoc analysis was conducted to determine the sources of the differences. Speech self-efficacy scores of the students who read 12-24 books in a year $(98.118 \pm 13.444)$ were higher when compared to those who read $1-5$ books per year $(86.849 \pm 12.831)$. Speech self-efficacy scores of the students who read $12-24$ books in a year $(98.118 \pm 13.444)$ were higher when compared to those who read 6-11 books per year $(86.767 \pm 10.773)$. 
It was found that the difference between group averages was not statistically significant as a result of one-way analysis of variance (ANOVA) conducted to determine whether there was a difference between the mean pretest effective speech and organization of speech content scores of the participating students based on the number of books read within the year variable.

Findings on the sub-problem of "Is there a difference between the posttest speech self-efficacy perception levels of the students based on gender?" are presented in Table 5 .

Table 5. Mean posttest speech self-efficiency scores based on gender

\begin{tabular}{|c|c|c|c|c|c|c|}
\hline & Group & $\mathrm{N}$ & Mean & $\mathrm{Sd}$ & $\mathrm{t}$ & $\mathrm{p}$ \\
\hline \multirow[t]{2}{*}{ Speaking before an audience Posttest } & Female & 55 & 25.034 & 4.824 & 0.364 & 0.717 \\
\hline & Male & 25 & 24.571 & 5.492 & & \\
\hline \multirow[t]{2}{*}{ Effective Speech Posttest } & Female & 55 & 23.848 & 3.134 & 1.115 & 0.268 \\
\hline & Male & 25 & 22.905 & 3.833 & & \\
\hline \multirow[t]{2}{*}{ Application of Speech Rules Posttest } & Female & 55 & 20.203 & 2.325 & 0.653 & 0.515 \\
\hline & Male & 25 & 19.762 & 3.448 & & \\
\hline \multirow{2}{*}{ Organization of Speech Content Posttest } & Female & 55 & 15.373 & 2.258 & 0.986 & 0.327 \\
\hline & Male & 25 & 14.762 & 2.897 & & \\
\hline \multirow[t]{2}{*}{ Speech Assessment Posttest } & Female & 55 & 12.237 & 1.579 & 0.222 & 0.825 \\
\hline & Male & 25 & 12.143 & 1.931 & & \\
\hline \multirow[t]{2}{*}{ Speech Self-Efficacy Posttest } & Female & 55 & 96.695 & 11.999 & 0.777 & 0.440 \\
\hline & Male & 25 & 94.143 & 15.308 & & \\
\hline
\end{tabular}

It was found that the difference between group averages was not statistically significant as a result of the t-test conducted to determine whether there was a statistically significant difference between the mean pretest speaking before an audience, effective speech, application of speech rules, organization of speech content, speech assessment and speech self-efficacy scores based on gender variable ( $p>0.05)$.

Posttest findings on whether the speech self-efficacy perception levels of the participating students varied based on the number of books read within a year are presented in Table 6.

Table 6. Mean posttest speech self-efficacy scores of the students based on the number of books read within a year

\begin{tabular}{llllllll}
\hline & Group & N & Mean & Sd & F & p & Diff. \\
\hline Speaking before an audience & 1-5 Books & 33 & 22.568 & 4.513 & 12.000 & $\mathbf{0 , 0 0 0}$ & $\mathbf{2}>\mathbf{1}$ \\
Posttest & 6-11 Books & 30 & 25.893 & 4.113 & & & $\mathbf{3}>\mathbf{1}$ \\
& 12-24 Books & 17 & 28.867 & 4.642 & & & $\mathbf{3}>\mathbf{2}$ \\
Effective Speech Posttest & 1-5 Books & 33 & 22.243 & 3.050 & 7.827 & $\mathbf{0 , 0 0 1}$ & $\mathbf{2}>\mathbf{1}$ \\
& 6-11 Books & 30 & 24.250 & 2.730 & & & $\mathbf{3}>\mathbf{1}$ \\
Application of Speech Rules & 12-24 Books & 17 & 25.733 & 3.712 & & & \\
Posttest & 1-5 Books & 33 & 19.595 & 2.793 & 2.812 & 0,066 & \\
Organization of $\quad$ Speech & 6-11 Books & 30 & 20.000 & 2.091 & & & \\
Content Posttest & 1-5 Books & 17 & 21.467 & 2.900 & & & \\
& 6-11 Books & 33 & 14.297 & 2.308 & 7.317 & $\mathbf{0 , 0 0 1}$ & $\mathbf{2}>\mathbf{1}$ \\
Speech Assessment Posttest & 12-24 Books & 17 & 15.536 & 2.134 & & & $\mathbf{3}>\mathbf{1}$ \\
& 1-5 Books & 33 & 11.867 & 2.386 & & & \\
6-11 Books & 30 & 12.643 & 1.471 & & & $\mathbf{3}>\mathbf{1}$ \\
Speech Self-Efficacy Posttest & 12-24 Books & 17 & 13.200 & 1.656 & & & \\
& $1-5$ Books & 33 & 90.189 & 11.438 & 11.101 & $\mathbf{0 , 0 0 0}$ & $\mathbf{2}>\mathbf{1}$ \\
& 6-11 Books & 30 & 98.321 & 10.569 & & & $\mathbf{3}>\mathbf{1}$ \\
& $12-24$ Books & 17 & 106.133 & 13.287 & & & $\mathbf{3}>\mathbf{2}$ \\
\hline
\end{tabular}

It was found that the difference between group averages was statistically significant $(\mathrm{F}=12,000 ; \mathrm{p}=0.000<0.05)$ as a result of one-way analysis of variance (ANOVA) conducted to determine whether there was a difference between the mean posttest speaking before an audience scores of the students who participated in the study based on the number of books read within the year variable. A supplementary post-hoc analysis was conducted to determine the sources of the differences. Speaking before an audience scores of those who read 6-11 books in a year $(25.893 \pm 4.113)$ were higher when compared to those who read 1-5 books per year (22.568 \pm 4.513$)$. Speaking before an audience scores of those who read 12-24 books in a year $(28.867 \pm 4.642)$ were higher when compared to those who read $1-5$ books per year $(22.568 \pm$ 4.513). Speaking before an audience scores of those who read $12-24$ books in a year $(28.867 \pm 4.642)$ were higher when compared to those who read 6-11 books per year $(25.893 \pm 4.113)$.

It was found that the difference between group averages was statistically significant $(F=7.827 ; p=0.001<0.05)$ as a result of one-way analysis of variance (ANOVA) conducted to determine whether there was a difference between the mean 
posttest effective speech scores of the students who participated in the study based on the number of books read within the year variable. A supplementary post-hoc analysis was conducted to determine the sources of the differences. Effective speech scores of those who read 6-11 books in a year $(24.250 \pm 2.730)$ were higher when compared to those who read 1-5 books per year $(22.243 \pm 3.050)$. Effective speech scores of those who read $12-24$ books in a year $(25.733 \pm 3.712)$ were higher when compared to those who read 1-5 books per year $(22.243 \pm 3.050)$.

It was found that the difference between group averages was statistically significant $(F=7.317 ; p=0.001<0.05)$ as a result of one-way analysis of variance (ANOVA) conducted to determine whether there was a difference between the mean posttest organization of the speech content scores of the students who participated in the study based on the number of books read within the year variable. A supplementary post-hoc analysis was conducted to determine the sources of the differences. Organization of the speech content scores of those who read 6-11 books in a year (15.536 \pm 2.134$)$ were higher when compared to those who read $1-5$ books per year $(14.297 \pm 2.308)$. Organization of the speech content scores of those who read 12-24 books in a year $(16.867 \pm 2.386)$ were higher when compared to those who read 1-5 books per year $(14.297 \pm 2.308)$.

It was found that the difference between group averages was statistically significant $(\mathrm{F}=8.406 ; \mathrm{p}=0.000<0.05)$ as a result of one-way analysis of variance (ANOVA) conducted to determine whether there was a difference between the mean posttest speech assessment scores of the students who participated in the study based on the number of books read within the year variable. A supplementary post-hoc analysis was conducted to determine the sources of the differences. Speech assessment scores of those who read 6-11 books in a year $(12.643 \pm 1.471)$ were higher when compared to those who read $1-5$ books per year $(11.487 \pm 1.521)$. Speech assessment scores of those who read 12-24 books in a year (13.200 \pm 1.656$)$ were higher when compared to those who read $1-5$ books per year $(11.487 \pm 1.521)$.

It was found that the difference between group averages was statistically significant $(F=11.101 ; p=0.000<0.05)$ as a result of one-way analysis of variance (ANOVA) conducted to determine whether there was a difference between the mean posttest speech self-efficacy scores of the students who participated in the study based on the number of books read within the year variable. A supplementary post-hoc analysis was conducted to determine the sources of the differences. Speech self-efficacy scores of those who read 6-11 books in a year $(98.321 \pm 10.569)$ were higher when compared to those who read 1-5 books per year $(90.189 \pm 11.438)$. Speech self-efficacy scores of those who read 12-24 books in a year (106.133 $\pm 13.287)$ were higher when compared to those who read 1-5 books per year $(90.189 \pm 11.438)$. Speech self-efficacy scores of those who read $12-24$ books in a year $(106.133 \pm 13.287)$ were higher when compared to those who read 6-11 books per year $(98.321 \pm 10.569)$.

It was found that the difference between group averages was not statistically significant as a result of one-way analysis of variance (ANOVA) conducted to determine whether there was a difference between the mean posttest application of speech rules scores of the participating students based on the number of books read within the year variable ( $p>0.05)$.

\subsection{Qualitative Findings}

In the study, the feelings and views of the students on the activity-based instruction of oral expression course were also investigated. For this purpose, students were asked to express in writing their feelings and thoughts before, during and after the activities they conducted. The written forms obtained from the students were analyzed using content analysis. Content analysis technique includes the stages of a) coding the data, b) identification of the themes, c) organization of the codes and the themes, and d) identification and interpretation of the findings (Yildirim and Simsek, 2016). The data obtained based on these principles were coded, the relationships between the themes and self-efficacy were established and categorized based on the correlation between the direct experiences, indirect experiences, verbal persuasion, and emotional state, which are the sources of self-efficacy belief, and verbal skills. In conclusion, students' replies were presented as direct quotes and the findings were defined and interpreted.

\subsubsection{Direct Experiences}

One of the four main sources of self-efficacy belief defined by Bandura (1986) is direct experiences.

Direct experiences are the self-achieved experiences of an individual. The formation of a strong sense of efficacy in individuals is possible through direct experiences of a particular individual. Accomplishment would lead to the formation of a strong self-efficacy belief, while failure would destroy this belief. In particular, if a failure occurs before the formation of a strong self-efficacy belief, the individual is likely to develop negative self-efficacy beliefs. Self-efficacy beliefs that are formed through direct experiences cannot be transferred from one situation to another like an existing habit. Thus, cognitive, behavioral and self-organization skills must be achieved before conducting or managing certain actions based on changing circumstances (Bandura, 1986, cited by Akkoyunlu, Orhan and Umay, 2005; Yavuzer and Koc, 2002).

Students were asked about their thoughts and feelings before, during and after the activities they conducted in the Oral 
Expression course. Almost all students stated that their participation in the activities during class instead of plain instruction was both enjoyable and enabled permanent learning and they learned by living. The activities where the students exhibited their verbal skills that they directly experienced were the first step towards the oral expressions that they would perform in the future. The students' views on the subject were as follows:

"I did not think that I would be able to speak before an audience without an obligation before I took the Oral Expression course. Now I do not have such precise boundaries. I can say that my self-confidence was negative about explaining certain things before an audience, but it is at normal level now. The oral expression course taught me that speech problems can be overcome, some of the several common pronunciation mistakes and other common errors that I used to make. I started to make sure that I no longer make those mistakes."

"This course taught me how to communicate in social settings and I also acquired the ability to discuss. It improved my pronunciation and taught me how to use the body language effectively during a conversation. Another achievement of the oral expression course was the skill to speak and control my feelings before an audience. I had some negative thoughts about giving presentations and speaking before an audience."

"Thanks to the activity I participated, I learned to speak without anxiety and feeling self-confident before an audience such as the classroom and express my views. "

"It was both more instructive and more enjoyable to conduct the oral expression course with activities. I was never bored in class. I was curious and enthusiastic about each class since the instructions included activities. If I had not presented in the class, I would still be afraid to speak before an audience. I still do a little, but not as much as before. I think this count contributed a lot both to me as and my friends."

"Activity-based instruction of the course improves the self-confidence of the individual. One gains a sense of responsibility."

"If the course included only theoretical instructions, we would not have the opportunity to gain the self-confidence needed for communication. But now we can speak before others with fluent and coherent sentences more confidently."

As seen in student statements, it can be argued that the course enabled the individuals to develop positive views on their abilities to make successful speeches before an audience, their self-efficacy beliefs and future speeches. The ability of the students to conduct successful presentations in the class that resulted in positive experiences would be closely related to the instructor. Since the student can conduct a successful presentation with the correct guidance and can strengthen the self-efficacy belief through direct experience, incorrect guidance can damage this belief when the student fails in conducting a successful presentation.

\subsubsection{Indirect Experiences}

Indirect experiences provided by social models are also factors that effect the formation and strengthening of self-efficacy beliefs. The effect of role models on self-efficacy belief is the strong influence of the perceived similarities between the individual and the person taken as a model. If the individual believes that the model is very similar, the success or failure of the model would have a more convincing effect on the individual. Individuals develop a judgement on their performance in a similar situation by observing and following the actions of other individuals that they consider to possess similar traits. On the other hand, self-efficacy beliefs will not be highly affected by the success or failure of the role model if the individual believes that the model does not resemble herself or himself that much (Bandura, 1986; Akkoyunlu, Orhan and Umay, 2005; Yavuzer and Koc, 2002).

As the oral expression course was instructed with activities throughout the semester, each week a group conducted their presentation and the other students viewed this presentation and took these performances as a model. In this process, they were influenced by each other and strived to perform better. The author observed this situation by the comments of the students about others "raising the bar" and through other student behavior. Throughout the semester, students stated the effect of their indirect experiences in the class on self-efficacy beliefs as follows:

"After the activity, I felt the lightness of being able to fulfill our duty. The applause we received and the statements of our friends that we raised the bar so high made me think that we did a good job with our presentation. All these feelings and the experiences I had during the activity were very beneficial."

"Due to the positive feedback I received after the event, I felt that I succeeded in that task and I felt a great relief. I was proud and my anxiety was gone."

"After the presentation, I was relieved off a huge load, and I was proud of myself and I understood that I did well as a result of the positive feedback of my classmates."

"The positive comments and reactions I received from my classmates that I had just addressed after our presentation improved by self-esteem and provided morale for future presentations." 
"After the presentation, I had thoughts like -Did I disgrace myself? Did my voice faltered? But, the positive reactions of my friends made me feel better. "

Besides the positive effects of indirect experiences on self-efficacy, adverse effects were also apparent in student statements. For example, a student said, "I felt like I lost my self-esteem, in spite of the fact that I like my class, I started to feel reluctant," emphasizing the impact of the class environment, in other words family, friends, etc., which are the indirect experiences that influence self-efficacy beliefs.

\subsubsection{Verbal Persuasion}

Verbal persuasion is the realistic positive verbal messages provided by teachers, friends, and family members in order to strengthen the students' belief that they can fulfill the tasks easily. The realistic positive verbal messages provided to students by teachers, friends, and family members about their oral expression would improve the self-efficacy beliefs of the students positively. Almost all students need verbal persuasion. The appreciation of student behavior, which is called a type of reinforcement in education, can also positively improve students' views on their performances. However, in the case of a task that exceeds the capacity of the student, verbal persuasion could have negative effects if the student fails to succeed in the task. The student views after the activity-based oral expression course were as follows:

"Thanks to the appreciative messages of our friends and teachers who were present at the presentation, I was able to overcome my anxiety to speak before an audience."

"After I finished speaking before the class, the appreciation and applause of the classmates made me very happy and removed my fears about speaking before an audience."

"The good comments that I received and the fact that they said I spoke well made me particularly happy. So now I believe that I did something right before an audience and I could do the same in the future."

"I was very happy when the class applauded us after the presentation and I realized from the expression of the teacher that (s)he liked it as well. I was really disturbed by the idea of speaking before the public, but now it really helped me to realize how enjoyable it was."

As seen in the above statements, verbal persuasion messages of both friends and teachers had positively contributed to the students' beliefs about themselves.

\subsubsection{Emotional State}

Both physical and emotional state of the individual is also partly influential in the formation of judgments about his abilities. When the individual feels good both physically and psychologically, the individual would more likely to succeed in an assigned task or to exhibit a desired behavior (Bandura, 1986; Akkoyunlu, Orhan and Umay, 2005; Yavuzer and Koc, 2002). Humans are biological creatures. Thus, education involves not only cognitive but also affective processes. Individuals' thoughts and emotions, in other words, their feelings are among the factors that can lead to success or failure when performing a task. The students expressed their emotional state during the activities as follows:

"Before taking the oral expression course, I was a person who was extremely excited and shy to speak before an audience, even timid, more passive, with the idea that when it is my turn I would not be able to form proper sentences and babble and would be ashamed before the audience, thus who cannot speak, cannot express and share his feelings. The fact that the course was instructed with presentations increased our achievements from the course."

"I always experienced difficulties in expressing my thoughts comfortably. I thought this was due to my shyness. Because I felt inadequate to speak before an audience. I had this psychology. After the course, I got a little more relaxed about speaking before an audience and at least now I can speak when it is my turn. I began to express my thoughts comfortably."

"This course proved to me that speaking before an audience was not a nightmare. Talking before an audience before the presentation was a horrible and painful experience for me. However, after the presentation started, I felt confident as things went well, I consider that was the biggest contribution."

"Speaking before an audience of about 50-60 people seemed a terrible and embarrassing situation especially before I knew how to do it. At the end of the presentation, when the teacher expressed positive remarks, a huge load has lifted off of me."

"After the activity, the course played an active role in refreshing my self-esteem by confronting my fears such as being before an audience and succeed in this process. For this reason, the most effective and functional part of this course was the fact that it was practical."

Student statements demonstrated that education takes place after a stage where the emotions are experienced intensively. In a study conducted by D'Mello, Lehman, Pekrun and Graesser (2012), it was stated that if contradictions, conflicts, anomalies, incorrect information and other inconsistent events are guided towards solutions or organization, they would 
be beneficial. Based on this finding and the student statements, it could be argued that taking the emotional state of the students into consideration in the organization, planning and implementation of the educational process would be beneficial.

\section{Discussion, Conclusion and Recommendations}

In the present study, the findings were presented based on the sub-dimensions of the utilized scale and overall scale score to determine the effect of activity-based oral expression course on speech self-efficacy perceptions of Psychological Counseling and Guidance Department students. It was determined that posttest "speaking before an audience," "effective speech," "organization of speech content," and "speech self-efficacy" scores of the students were higher than pretest speech self-efficacy scores. Based on these findings, it can be stated that the activity-based oral expression course played a significant role in improving the students' speech self-efficacy perceptions. Ciftci and Taskaya (2010) reported that there was a significant positive correlation between the communication skills and self-efficacy perceptions of pre-service classroom teachers. The findings of the abovementioned study and the present study demonstrated that the verbal skills of the students would improve since activity-based oral expression course increased speech self-efficacy perceptions of the students. Katranci and Kusdemir (2015) investigated the effects of the practices conducted in oral expression course on the speech anxiety of pre-service teachers and reported that the speech anxiety levels of pre-service teachers decreased after the oral expression course. This finding demonstrated that applications conducted in oral expression course also has an effect on anxiety, which is another factor in the affective dimension of speech.

In the present study, it was observed that there was no significant difference between pretest and posttest speech self-efficacy scores based on the gender variable. Similar to the present study findings, it was reported in previous studies that there was no significant difference between the speech self-efficacy perceptions of pre-service teachers based on the gender variable (Akin, 2016; Ciftci and Taskaya, 2010; Yilmaz and Cimen, 2008; Günay, 2003). Contrary to the findings of the present study, certain studies in the literature reported that speech self-efficacy perception levels of female pre-service teachers were higher than that of male pre-service teachers (Katranci, 2014; Kilcigil, Bilir, Ozdinc, Eroglu and Eroglu, 2009; Ozerbas, Bulut and Usta, 2007). It is considered that the differences between verbal skills of pre-service teachers based on the gender variable could be due to regional differences and differences in the educational levels related to the respective study groups.

According to the pre-test results based on the number of books read within a year, it was determined that there was a significant difference between "speaking before an audience", "application of speech rules", "speech assessment" and "speech self-efficacy" mean scores. It was found that the students who read between 12-24 books per had higher self-efficacy scores when compared to those who read between 1-5 and 6-11 books per year. According to the pre-test results, it was determined that there was no significant difference between the "effective speech" and "organization of speech content" sub-dimensions based on the number of books read in a year. According to the posttest results for the same variable, the mean "speaking before an audience scores of the students who read between 12-24 books were higher than those who read 1-5 and 6-11 books per year and the scores of the students who read 6-11 books per year were higher than those who read 1-5 books per year. It was found that the "effective speech", "organization the speech content" and "speech assessment" subscale scores of the students who read 6-11 books per year were higher than those who read between 1-5 and 12-24 books per year. Mean "speech self-efficacy" scores of the students who read between 6-11 books were higher than those who read 1-5 books, those who read between 12-24 books were higher than those who read between 1-5 and 6-11 books per year. The speech self-efficacy posttest scores of the students did not differ only in the dimension of "application of speech rules" based on the number of books read in a year variable. Based on the above findings, it can be argued that the number of books read in a year increased speech self-efficacy score both in pretest and posttest results. It is considered that the increase in the number of books read increased the speech self-efficacy of the students and thus, increasing their achievements in verbal skills. Further studies that would investigate the relationship between students' speech self-efficacy levels and verbal skills based on the said variable could contribute to the literature.

Based on the qualitative study findings, the students expressed positive views on the activity-based oral expression course and the factors of "direct experiences", "indirect experiences", "verbal persuasion" and "emotional state," which are sources of self-efficacy belief. The students, who actively participated in the instruction process in the oral expression course, stated that the activity-based instruction of the course played a significant role in the improvement of their self-efficacy beliefs.

The speech self-efficacy perception, which is a part of the affective dimension of the oral expression education process, includes the thoughts of the individuals about whether they could make a successful speech. In order to improve this perception positively, it is considered that students should actively participate in oral expression courses. 
In the present study, the effect of the activity-based oral expression course on students' speech self-efficacy perceptions was determined. It could be argued that the determination of the effects of the courses that would be instructed in the same manner on other affective factors such as anxiety, attitude, etc. could contribute to the literature.

It is considered that the attention paid by the faculty members that provide verbal skills education to the affective dimensions of the students and planning of the courses to improve the self-efficacy perceptions of the students would be beneficial.

\section{Resources}

Akın, E. (2016). Türkçe öğretmen adaylarının konuşma özyeterliklerinin çeşitli değişkenler açısından incelenmesi (Siirt üniversitesi örneği). Route Educational and Social Science Journal, 3(1), 75-90. https://doi.org/10.17121/ressjournal.476

Akkoyunlu, B., Orhan, F., \& Umay, A. (2005). Bilgisayar öğretmenleri için bilgisayar öğretmenliği özyeterlik ölçeği geliştirme çalışması. Hacettepe Üniversitesi Eğitim Fakültesi Dergisi, 29, 1-8.

Aktaş, Ş., \& Gündüz, O. (2009). Yazılı ve sözlü anlatım. Ankara: Akçağ Publishing.

Ayan, S., Katrancı, M., \& Melanlığlu, D. (2014). Awareness level of teacher candidates' in terms of their Turkish language sufficiency: A qualitative research. International Journal of Academic Research Part B, 6(29), 137-143. https://doi.org/10.7813/2075-4124.2014/6-2/B.21

Bandura, A. (1986). Social foundations of thought and action: A social theory. Englewood Cliffs, NJ: Prentice-Hall.

Bandura, A., \& Locke, E. A. (2003). Negative self-efficacy and goal effects revisited. Journal of Applied Psychology, 88(1), 87-99. https://doi.org/10.1037/0021-9010.88.1.87

Başaran, M., \& Erdem, İ. (2009). Öğretmen adaylarının güzel konuşma becerisi ile ilgili görüşleri üzerine bir araştırma. Kastamonu Ĕgitim Dergisi, 17(3), 743-754.

Bus, A. G., van IJzendoorn, M. H., \& Pellegrini, A. D. (1995). Joint book reading makes for success in learning to read: A meta-analysis on intergenerational transmission of literacy. Review of Educational Research, 65, 1-21. https://doi.org/10.3102/00346543065001001

Creswell, J. W. (2003). Research design: Qualitative, quantitative, and mixed methods approaches. Thousand Oaks, CA: Sage

Creswell, J. W., \& Plano Clark, V. L. (2007). Designing and conducting mixed methods research. Thousand Oaks, CA: Sage

Çiftçi, S., \& Taşkaya, S. M. (2010). Sınıf öğretmeni adaylarının öz yeterlik ve iletişim becerileri arasındaki ilişki. E-Journal of New World Sciences Academy, 5(3), 921-928.

D’Mello, S. K., Lehman, B., Pekrun, R., \& Graesser, A. C. (2014). Confusion can be benefical for learning. Learning \& Instruction, 29(1), 153-170. https://doi.org/10.1016/j.learninstruc.2012.05.003

Doğan, Y. (2009). Konuşma becerisinin geliştirilmesine yönelik etkinlik önerileri. Türk Eğitim Bilimleri Dergisi, 7(1), 185-204.

Erdem, İ., Altunkaya, H., \& Ateş, A. (2017). Türkçeyi Yabancı dil olarak öğrenenlerin okur özyeterlikleri ile okuduğunu anlama becerileri arasındaki ilişki. International Journal of Language Academy, 5(4), 74-86. https://doi.org/10.18033/ijla.3622

Günay, K. (2003). Sinıf yönetiminde öğretmenlerin iletişsim becerilerinin değerlendirilmesi. Unpublished master's thesis, Çukurova University, Adana.

Katrancı, M. (2014). Öğretmen adaylarının konuşma becerisine yönelik öz yeterlik algıları. Bartın Üniversitesi Eğitim Fakültesi Dergisi, 3(2), 174-195. https://doi.org/10.14686/BUEFAD.201428177

Katrancı, M., \& Melanlıŏglu, D. (2013). Öğretmen adaylarına yönelik konuşma öz yeterlik ölçeği: Geçerlik ve güvenilirlik çalışması, International Journal of Social Science, 6(6), 651-665.

Kılcıgil, E., Bilir, P., Özdinç, Ö., Eroğlu, K., \& Eroğlu, B. (2009). İki farklı üniversitenin beden eğitimi ve spor yüksekokulu öğrencilerinin iletişim becerilerinin değerlendirilmesi. Spormetre Beden Eğitimi ve Spor Bilimleri Dergisi, 7(1), 19-28.

Lopez, F. G., Lent, R. W., Brown, S. D., \& Gore, P. A. (1997). Role of social-cognitive expectations in high school students' mathematics-related interest and performance. Journal of Counseling Psychology, 44, 44-52. https://doi.org/10.1037/0022-0167.44.1.44 
Mert Cüce, A. P. (2012). Etkinlik temelli matematik öğretimi yapılan sınıf ortamından yansımalar: Aksiyon araştırması. Unpublished master's thesis, Karadeniz Technical University, Trabzon.

Oğuz, A. (2009). Öğretmen adaylarının sözlü ve yazılı anlatım becerilerine ilişkin öz yeterlik algıları. Elektronik Sosyal Bilimler Dergisi, 8(30), 18-42.

Özbay, M. (2005). Sesle ilgili kavramlar ve konuşma eğitimi. Millı̂ Eğitim, 168.

Özerbaş, M. A., Bulut, M., \& Usta, E. (2007). Öğretmen adaylarının algıladıkları iletişim becerisi düzeylerinin incelenmesi. Ahi Evran Üniversitesi Kırşehir Eğitim Fakültesi Dergisi (KEFAD), 8(1), 123-135.

Pajares, F., Johnson, M. J., \& Usher, E. L. (2007). Sources of writing self efficacy beliefs of elementary, middle, and high school students. Research in the Teaching of English, 42, 104-120.

Schunk, D. H. (2003). Self-efficacy for reading and writing: Influence of modeling, goal setting, and self-evaluation. Reading \& Writing Quarterly, 19(2), 159-172. https://doi.org/10.1080/10573560308219

Schunk, D. H. (2008). Learning theories. An Educational Perspective (5thEd.). Pearson Education, Upper Saddle Hill, NJ.

Schunk, D. H., \& Zimmerman, B. J. (2007). Influencing children's self-efficacy and selfregulation of reading and writing through modeling. Reading \& Writing Quarterly, 23, 7-25. https://doi.org/10.1080/10573560600837578

Sever, S. (2001). Öğretim dili olarak Türkçenin sorunları ve öğretme-öğrenme sürecindeki etkili yaklaşımlar. Ankara Üniversitesi Eğitim Bilimleri Fakültesi Dergisi, 34(1), 11-22.

Ülper, H., \& Bağcı, H. (2012). Türkçe öğretmeni adaylarının öğretmenlik mesleğine dönük öz yeterlik algıları. Turkish Studies, 7(2), 1115-1131.

Ünalan, Ş. (2007). Sözlü anlatım. Ankara: Nobel Publishing.

White, A. G. (2009). Ninth and tenth grade student's mathematics self-efficacy beliefs: The sources and relationship to teacher classroom interpersonal behaviors. Unpublished doctoral dissertation, Department of Secondary Curriculum and Instruction, The University of Alabama.

Wood, R., \& Bandura, A. (1989). Impact of conceptions of ability on self-regulatory mechanisms and complex decision making. Journal of Personality and Social Psychology, 56(3), 407-415. https://doi.org/10.1037/0022-3514.56.3.407

Yavuzer, Y., \& Koç, M. (2002). Eğitim fakültesi öğrencilerinin öğretmen yetkinlikleri üzerinde bir değerlendirme. Niğde Üniversitesi Ĕ̈itim Fakültesi Dergisi, 1(1), 35-43.

Yıldırım, A., \& Şimşek, H. (2016). Sosyal bilimlerde nitel araştırma yöntemleri. Ankara: Seçkin Publishing.

\section{Copyrights}

Copyright for this article is retained by the author(s), with first publication rights granted to the journal.

This is an open-access article distributed under the terms and conditions of the Creative Commons Attribution license which permits unrestricted use, distribution, and reproduction in any medium, provided the original work is properly cited. 